\title{
Handwriting examinations in Poland
}

\author{
MAREK LEŚNIAK \\ Department of Criminalistics \\ Faculty of Law and Administration \\ University of Silesia, Poland
}

\section{Introduction}

Professional handwriting examinations in Poland enjoy a 100-yearlong tradition. But the text is about situation of such examinations currently. The present author's purpose is to depict the scientific condition of handwriting examinations and the position taken in practice. The handwriting expert's opinion is the most often treated as the part of document examination ${ }^{1}$. Within handwriting examination the specialist literature distinguishes three different scopes of examination: identification comparative examinations, examinations relating to pathology of handwriting, examination relating to psychology of handwriting. It is possible to encounter with all kinds of examination in Polish court. Therefore the present disquisition should take all mentioned scope into considerations

${ }^{1}$ Kryminalistyka, ed. J. Widacki, C.H. Beck, Warszawa 2012, pp. 225-300; M. Goc, Wspótczesny model ekspertyzy pismoznawczej, Wolumina.pl, Warszawa-Szczecin 2015, pp. 38-46; M. Goc, A, Łuszczuk, E. Oleksiewicz, "Dokument jako ślad kryminalistyczny”, [in:] Ślady kryminalistyczne. Ujawnianie, zabezpieczenie, wykorzystanie, ed. M. Goc, J. Moszczyński, Difin, Warszawa 2007, pp. 251-252; E. Gruza, M. Goc, J. Moszczyński, Kryminalistyka - czyli rzecz o metodach śledczych, Wydawnictwa Akademickie i Profesjonalne, Warszawa 2008, pp. 360-410. 
As the result of the semiotic and praxeological analysis, as well as through the interpretation of the legal registrations, mainly concerning so called "evidence law", the set of elements have been established, from the value of which depends the evidential value of particular opinion based on handwriting knowledge, commissioned by judicial bodies for particular criminal, civil and administrative case ${ }^{2}$. Into that set of elements have been included: the property of the written assignment, legal admissibility of the methods used by handwriting experts, approximation of the main judicial proceedings fact and the fact which is concerned by the expert witness' opinion, identification value of the methods used by the expert, the property of the methods used by the expert witness, including identification value of the methods, psychological pre-orientation of judicial bodies in regard to the opinion based on handwriting knowledge and the competence of the handwriting expert. The mentioned elements will be used during the presentation of issues concerning professional handwriting examinations in Poland.

It is impossible for the present text to mention all significant Polish researches who dealt with handwriting and to list all their publications from the scope. As mentioned above the text has not come into being with the aim of providing with the list. The interested may refer to Polish Criminalistics Bibliography which subsequent parts are issued by The Forensic Association of Poland.

\section{Features of handwriting analysis}

The variety of factors affecting the range of changeability of graphic realisation performed by a particular person at a particular time and the enormous number of features which concur to the description of the particular written assignment has been noticed. Those properties cause that the study concerning the frequency of the certain changeability range occurrence (the natural one as well as the one created through the intention attempts of the manuscript's author) is not very advanced. The future for sure belongs to further research in this area to be conducted on large population, using features during measuring and also calculations con-

2 M. Leśniak, Wartość dowodowa opinii pismoznawczej, B.S. Training, Pińczów 2012, pp. 27-29.

Nowa Kodyfikacja Prawa Karnego 45, 2017

(C) for this edition by CNS 
cerning their value made by adequate computer programs. This changeability, however, complicates the study on the accuracy of particular methods based on handwriting science. It is still not possible to conduct a statistical calculation of the probable repetition of a particular configuration of the writing feature value in Polish population. As a result, the level of conviction about the genuineness included in conclusion of the expert's decisions is based mainly on subjective possibility (psychological). It was emphasized that in empiric studies there are no methods which would give $100 \%$ adequate settlement and any other settlement based on handwriting science also cannot give such certainty. It appeals only to psychological probability as it is mentioned in the text below.

\section{Significance for judicial proceedings}

Circumstances arising according to the expert witness may pertain to the main fact that occurs in the criminal, civil or administrative case or to the peripheral fact. The expert's establishments concerning handwriting identification usually relate to the main fact. Comparative experts' opinion in some cases may, however, refer to the peripheral fact. The arrangements concerning the pathology and psychology of handwriting (if such knowledge is not used "assistantly" [auxiliary?] in the identification study) and the arrangements concerning handwriting psychology refer to the peripheral fact. If anything concerns expert's examination of written expressions of intention (mostly testaments), in Polish civil cases it is not legal admissible to replace a psychiatrist's opinion or a psychologist's opinion with a handwriting expert's opinion form the scope of pathology. Expert's opinion relating to psychology of handwriting may be used in order to create a psychological profile (to determine the male/female sex too) of a writer in case of an anonymous letter.

Describing conception of the value of the expert's opinion is not possible without referring to a specific theory of proving in court. It may be based on the inductive concept of court reasoning and proving, regarding also the probabilistic nature of all actual decisions made while conducting a case based on enactment ${ }^{3}$.

3 J. Konieczny, "Indukcjonistyczne ujęcie dowodu sądowego w procesie karnym", [in:] Materiaty VIII Sympozjum Metodologicznego Kryminalistyki i Nauk Pokrewnych,

Nowa Kodyfikacja Prawa Karnego 45, 2017

(C) for this edition by CNS 
In criminal cases the need for using handwriting comparative expert's opinion may be connected with every offences, when a questioned handwriting appears as a piece of evidence within it. But in the Polish Penal Code (act of 6 June 1997) there is an offence in case of which it is practically impossible for criminal court to sentence a particular defendant without basing on a professional document expert's opinion. It is a very often used a handwriting comparative opinion. According to article 270 $\S 1$. "Whoever, with the purpose of using it as authentic, forges, or counterfeits or alters a document or uses such a document as authentic shall be subject to a fine, the penalty of restriction of liberty or the penalty of deprivation of liberty for a term of between 3 months to 5 years. $\S 2$. The same punishment shall be imposed on anyone, who fills in a form bearing someone else's signature, contrary to the will of the signatory and to his detriment or indeed uses such a document". It is worthy of remark that Polish legislator uses the notion "document" in very wide meaning 4 . According to the content of article $115 \S 14$ "document" may be any object with which specific right is linked or which in connection with its content may constitutes a proof of law, a legal relation or a circumstance of legal significance. In 2015 Polish courts sentenced 5975 defendants who was accused of forging documents ${ }^{5} .2735$ of them were imprisoned (but only 216 without suspending the sentence). Therefore results of handwriting expert's opinions are of significant importance for judicial proceedings.

\section{The issue of scientific character of handwriting expert' opinions}

In Polish specialist literature for about 20 years has been discussing the issue of scientific character of methods used by handwriting experts. Up until the time the thesis on scientific character of this kind of

ed. J. Konieczny, Uniwersytet Śląski, Katowice 2012, pp. 27-29; T. Widła, Ocena dowodu z opinii biegłego, Uniwersytet Śląski, Katowice 1992, pp. 97-107; M. Leśniak, op. cit., pp. 20-27.

${ }^{4}$ R. Cieśla, Technical Examination of Documents, Wydawnictwo Uniwersytetu Wrocławskiego, Wrocław 2006, pp. 37-39.

5 http://statystyka.policja.pl/st/kodeks-karny/przestepstwa-przeciwko-15/63643, Podrabianie-dokumentow-art-270.html (15.04.2017).

Nowa Kodyfikacja Prawa Karnego 45, 2017

(C) for this edition by CNS 
examination was not disputed one ${ }^{6}$. Polish scientists were examining a debate about it that was being developed in American courts ${ }^{7}$. They took into consideration the Daubert test (the first principles scientific collection), that had changed criteria for the admissibility of scientific evidence in American courts. Using this expert evidence filter part of American judges stop treating handwriting experts' opinion as a scientific evidence. It should be emphasized that the Daubert test may be the lodestar in nonAmerican courts but it is specific to American legal system. That's the reason why the present text chooses the highly advanced J. Konieczny's modification ${ }^{8}$. Individual study method based on handwriting knowledge in various scales deserves to be put in a category of "scientific" methods - some part of them does not deserve to be put in that category at all. However, taking into consideration the fact that "scientific" is a gradable, multivalent feature (not dichotomous) and is connected with the level of standardization of methodology (at procedure of which the result of the empiric study is used) and also the knowledge of its accuracy and reliability, some part of identification study methods of handwriting as well as concerning handwriting pathology and psychology is "scientific". Together with their more precise standardization (of course, very important for judges should be an answer to what extent are the standards based on empirical findings) and deeper research of the size of uncertainty area their level of "scientific part" for sure may be much higher.

Current legal rules does not contain regulations, which judicial bodies would be able to use during making actual arrangements on the opinions based on handwriting knowledge. The above statement concerns all

${ }^{6}$ A. Feluś, "O tzw. nienaukowości ekspertyzy pisma ręcznego", [in:] Materiały XI Wrocławskiego Sympozjum Badania pisma, ed. Z. Kegel, Uniwersytet Wrocławski, Wrocław, 2006, pp. 63-70.

${ }^{7}$ See among other things: T. Tomaszewski, "Badania pismoznawcze w Stanach Zjednoczonych: rzemiosło czy nauka", [in:] Wpływ badań eksperymentalnych na wartość dowodowa ekspertyzy dokumentów, ed. Z. Kegel, Uniwersytet Wrocławski, Wrocław 2008, pp. 399-408; P. Gidrwoyń, "Rzemiosło czy nauka: sprawy U.S. v. Prime, U.S. v. Saelee, U.S. v. Rutherford", [in:] Wplyw badań eksperymentalnych..., pp. 117-128; J. Wójcikiewicz, Dowód naukowy w procesie sądowym, Wydawnictwo Instytutu Ekspertyz Sądowych, Kraków 2000, p. 22.

8 J. Konieczny, "Polygraph examination as scientific evidence", European Polygraph 2010(3), pp. 117-120. 
the kinds of identification arrangements; it means that together with the arrangements based on handwriting science, the evidence in a particular criminal, civil or administrative case may occur also an arrangements concerning handwriting pathology or psychology.

In Polish literature regarding the subject matter, there is only little information about the study results concerning the accuracy of the individual handwriting scientific methods. In order to conduct a meta-analysis of the empiric results of the report we should inquire from literature concerning the subject matter, providing for the distinctness of the used study procedures. Generally, it has been established that the accuracy of the currently used methods concerning handwriting identification study is actually above $80 \%$. The margin of error of the graphically-comparative method used in Poland, in the relation to Polish population, is about $10 \%$ - diagnostic value of the method, however, has been analysed only in one Polish empiric study. It is very mysterious issue, that there is only one empirical study of the handwriting identification method accurate while so many people are sentenced owing to the handwriting expert's opinion. The research was made by J. Widacki in $1976^{9}$. He arranged situation that participants of the experiments took a paper package from door-keeper's room. Then experienced experts used different identification method to match part of participants who had left their traces. The polygraph examination accuracy was compared to: the handwriting examination accuracy, the accuracy of recognizing by an eyewitness (doorkeepers) and the dactyloscopy examination accuracy. The handwriting examination accuracy reached about 90 percentage.

In the case of methodology concerning pathology and psychology of handwriting, excluding the method of establishing the sex of the manuscript writer T. Widly, in Poland we do not use expanded methodologies of this kind, which are mainly described in German and French literature. There is simple lack of Polish empiric literature concerning the accuracy of such method. The accuracy of T. Widla's method reaches 80 percentage ${ }^{10}$. The method is highly standardized and the standards based on empirical researches.

9 J. Widacki, Wartość diagnostyczna badania poligraficznego i znaczenie kryminalistyczne, Uniwersytet Jagielloński, Kraków 1976.

10 T. Widła, Cechy ptci w piśmie ręcznym, Uniwersytet Śląski, Katowice 1986. 


\section{Forms of expert's conclusion used in Poland}

Experts formulate conclusion as: categorical, probable and inconclusive $^{11}$. Probable conclusions often are graded (probable, highly probable, very highly probable). An expert's evaluation of probability of a specific finding is subjective. It relates to the expert's experience only. There are few empiric findings about the likelihood of a specific set of handwriting characteristics values repeating in Polish population. Of course, too large factors influencing on handwriting may cause it impossible. But such data should be collected with the frequency with which sets of characteristics occur in the Polish and other populations. One should agree with assertion that research on frequency of features develops the discipline ${ }^{12}$ and gives scientific background for handwriting examination.

The vast majority of Polish researches and experts based on the axiom that handwriting is individual ${ }^{13}$. It is not scientific because it is not possible empirically to put such thesis under falsification. It is possible that a specific handwriting is individual one. But is it possible to find it on the level of characteristics that an expert may evaluate at present? Many scientists are afraid of consequences connected with rejecting of the axiom. Polish prosecutors and judges expect categorical conclusions. During studying and a legal apprenticeship they were not preparing for using expert's non-categorical conclusions. There are researches who make a demand for rejection of "error of individualization" and expert's categorical conclusion ${ }^{14}$. According to the third, moderate position, experts may formulate the conclusion as categorical one but they should express it verbally as relating to only psychologically understanding of "certainty"15. Experts should use such phrases as: "I think that...",

11 M. Goc, "Poziom kategoryczności wniosków końcowych w opiniach pismoznawczych”, Problemy Kryminalistyki 2011, 272, pp. 56-65.

12 M.J. Sachs, J.K. Koehler, "The coming paradigm shift in forensic identification science", Nature 2005, vol. 309, pp. 892-895.

13 See for example: M. Kała, D. Wilk, J. Wójcikiewicz, Ekspertyza sądowa, Wolter Kluwer, Warszawa 2017, pp. 554-555; A. Feluś, "Indywidualność pisma a pomyłki biegłego", Problemy Kryminalistyki 1985, 168, pp. 216-221.

14 J. Konieczny, "Kryzys czy zmiana paradygmatu kryminalistyki", Państwo i Prawo 2012(1), pp. 10-15.

15 T. Widła, Ocena dowodu ..., pp. 69-70. 
"I claim that...". The present author asserts that it is important to separate scientific and non-scientific issues. Scientific elements of professional experts are prone to a quality check. It may concern a measurement or an estimate of handwriting characteristics values or treat them as either similarities or dissimilarities. It is transparent to determine that a range of changeability of comparative writings characteristics includes questioned writing characteristics values. Transitions from such findings to categorical conclusions about writing the specific handwriting by an individual lose their transparency. It is based mainly on an expert's experience. The trial decision-makers should be aware of that fact. They (mostly judges) should get clear information what parts of the expert's opinion are based on empirical generalizations and what part of it is based only on different kinds of generalizations.

\section{Qualifications of judicial decision-makers to evaluate handwriting experts' opinions}

The adequate assessment of the evidence value of handwriting science-based opinion demands an adequate knowledge and abilities of the trial decision-maker who makes an assessment. Within the assessment procedures and making decisions concerning the value of the prolonged opinion, judicial bodies should know which elements of the opinion they should pay attention to. In Poland the current way of educating judges and prosecutors does not give us any chance to gain adequate qualifications in this area. The symptom of it is not showing interest in the accuracy of methods used by the expert. How is it possible to make an assessment of a specific expert opinion without information about the accuracy of the expert method? During the education judges are trained to ask forensic experts appropriate questions in a trial decision about admitting a handwriting expert's opinion in evidence. But they are not prepared to assess submitted opinion. It is displayed in helplessness concerning confrontations of expert's witnesses. It very often occurs that judges are looking for another expert in such situations. Then such a decision-maker may be driven by numbers of opinions (instead of by strength of experts' arguments). 
It is possible to distinguish three stages of assessments of an expert's opinion: the stage of a priori assessment, the stage of a individual a posteriori assessment and the stage of final a posteriori assessment ${ }^{16}$. The first stage includes making assessment that ascertains a particular issue which requires the possession of special knowledge. According to Polish criminal proceedings (article $193 \S 1$ of the Code of Criminal Procedure; act of 6 June 1997) appearing two premises (the matter requires the special knowledge and it is significantly important for the case) obliges the decision-maker to turn to an expert. There are no other possibilities to explain the fact. An interesting thing is that the Polish Code of Civil Procedure gives possibilities to the judge to examine handwritings (article $254 \S 1$ of the Code of Civil Procedure) without experts. The regulation is a relic of a bygone age (the situation from over 100 hundreds years) when judges' knowledge was comparable to an expert's knowledge. The first stage of assessments includes also: the issue of choosing an expert or an institution, the form of an expert's opinion (written or unwritten one), a date for its submission. According to the article $200 \S 2$ of the Polish Code of Criminal Procedure every expert's opinion should be supply among other things with substantiation ("a report on activities and findings and conclusions drawn from them"). The second stage includes the assessments of a particular expert opinion but concerns nothing but the opinion. The opinion is checked paying special attention to its completeness and intelligibility. The expert is not a "judge of fact". Every opinion is subjected to judges' free assessment of evidence. Judges are "a supreme expert witness" in Poland. If a court doesn't acknowledge an expert opinion it should demand the expert submit another opinion or it should put the same questions to another expert. Such legal construct must demand that judges are prepared for controlling of expert's evidence ${ }^{17}$. In practice such control is not possible because judges have not an appropriate knowledge of first principles concerning forensic experts' methods. For that reason judges sentenced people basing on poor quality experts' opinion. The third stage is connected with an expert opinion as-

16 T. Widła, Ocena dowodu ..., pp. 108-111.

17 J. Dziewanowska, J. Studzińska, "Assessment of export evidence in Polish Court proceedings in comparison to other European countries", Problems of Forensic Sciences, 2016, vol. 106, p. 463. 
sessment in the context of other pieces of evidence. The courts decisionmakers often become helpless in face of a contradiction between expert's opinions.

Therefore prosecutors and judges are trained quite well to make an assessment in the initial stage. Lack of knowledge concerns second and third stages of making an experts' opinions assessment.

\section{Qualifications of handwriting experts. Management of quality}

The qualifications of the handwriting experts should have already been verified in a proper way before listing them onto the experts' list provided by the administration of justice. In this area there is also lack of standardized rules, and the observation of the usage shows that very often happens that judges gain information from people who has neither adequate knowledge nor abilities. In Poland there is also lack of competency tests, which should be available for every person conducting the expert's report. Judicial bodies should head such tests' results while choosing the expert's witness to a particular case.

In Poland until 1989 it was very difficult to become an expert in a court. There were two ways of reaching it - through forensic laboratories of police forces or forensic departments at universities. Then it went from one extreme to the other. At present there are a lot of private schools that offer postgraduate courses in document examination. It happens very often that such courses are not carried out by document (handwriting) experts ${ }^{18}$. Their participants apply for putting them on lists of experts administrated by the president of regional courts. The ordinance of the Minister of Justice of 24 January 2005 on court experts requires possessing theoretical and practical special knowledge in a given discipline from candidates to the list. Possessing the knowledge is verified only by means of documents - course certificates too. As a result of such prac-

18 M. Leśniak, S. Ławrentjew, "Przesłanki wpisu na listę biegłych zakresu badań dokumentów w sądach okręgowych w Częstochowie, Gliwicach i Katowicach — analiza praktyki", [in:] Dokument i jego badania, ed. R. Cieśla, Uniwersytet Wrocławski, Wrocław 2014, pp. 211-214. 
tices there are handwriting court experts in the hundreds. The list of only one regional court (in Częstochowa) may include above fifty experts in handwriting examination. People choose the specialty because of law expenditures. Prosecutors and judges often are urged to choose the cheapest experts and the fastest one. There is not a national register of expert's opinion. There are not universally used proficiency tests (such tests are carried out only in police forces laboratory). There are not a national quality management system to ensure adequate quality of expert's opinion. All the factors result in an organizational mess. It does not depend on politically motivated decisions. Unfortunately, subsequent ministers treat the issues as without significance for results of an opinion poll.

The legal system and accepted rules do not allow experts to learn from their own mistakes. Moreover, the legislator introduces rules that support persisting in errors (for instance: during a confrontation of the expert's witness). According to the Polish Penal Code (art. $233 \S 4 \mathrm{a}$ ) it is possible to punish expert witness for an unintentional falsified opinion. Therefore experts may be sentenced for making mistakes (as the result of negligence or the result of lack of knowledge or skills). It does not create favorable conditions for owning up to mistakes. That way the legislators wanted ineffectually to upgrade the quality. As a matter of fact the expression "unintentional falsifying" is an oxymoron. Most Polish forensic scientists demand a change of the present situation ${ }^{19}$.

\section{Scientific background}

Apart from the mentioned lack of research on the handwriting method accuracy there are a lot of centers which deal with handwriting examination scientifically. It includes: forensic departments of the universities in Katowice, Poznań, Warsaw, Wrocław, the psychological department in Lublin, the Central Forensic Laboratory of the Police Headquarters in Warsaw and the Institute of Forensic Research in Cracow. There is no way to list hundreds Polish research on handwriting in the present text. As an example, the research concern:

19 R. Cieśla, Technical examanation ..., p. 81. 
- measurable handwriting characteristics ${ }^{20}$,

— influence of particular somatic disorders on handwriting ${ }^{21}$,

- influence of particular mental disorders on handwriting ${ }^{22}$,

- influence of alcohol on handwriting ${ }^{23}$,

- methodological aspects of handwriting examination ${ }^{24}$,

- connections between personality features and handwriting char$\operatorname{acteristics}^{25}$,

- items of information that may be derived from signatures ${ }^{26}$,

- a frequency signatures' characteristics ${ }^{27}$,

- new techniques of graphical and comparative analysis that allow handwriting experts to analyze new characteristics ${ }^{28}$,

- the interdisciplinary nature of the modern forensic handwriting analysis $^{29}$.

The very important thing is an exchange of experts' experiences. In Poland it is possible to do it mainly owing to the fact, that Forensic Departments of University in Wrocław for many years organized Wrocław

${ }^{20}$ A. Koziczak, Metody pomiarowe w badaniach pismoznawczych, Instytut Ekspertyz Sądowych, Kraków 1997.

21 M. Całkiewicz, Kryminalistyczne badania patologicznego pisma ręcznego, Akademia im. Leona Kuźmińskiego w Warszawie, Warszawa 2009; S. Skubisz, Dowód z ekspertyzy pisma patologicznego, Wolters Kluwer, Kraków 2004; T. Widła, “Z problematyki patologii pisma", [in:] Kryminalistyka i nauki penalne wobec przestępczości, ed. H. Kołecki, Wydawnictwo Poznańskie, Poznań 2008, pp. 139-172.

22 A. Buczek, M. Leśniak, "Z badań nad pismem schizofreników w okresie remisji”, Postepy Psychiatrii i Neurologii 2000, 9, suplement 1.

23 J. Pobocha, M. Legień, “Zmiany poalkoholowe w piśmie ręcznym”, Problemy Kryminalistyki, 1981, pp. 151-152.

24 E. Gruza, "Błędy w opiniach biegłych”, Problemy Współczesnej Kryminalistyki 2005, IX; T. Tomaszewski, “Czynniki uwzględniane w badaniach autentyczności podpisów”, Człowiek i Dokumenty 2010, 16.

25 B. Gawda, Pismo a osobowość człowieka, Uniwersytet Marii Curie-Skłodowskiej, Lublin 2000.

26 A. Feluś, Podpisy. Studium z pismoznawstwa kryminalistycznego, Uniwersytet Śląski, Katowice 1987.

27 S. Matuszewski, "Natural variation in length of signature components", Problem of Forensic Science, 2011, LXXXVII.

28 M. Goc, Współczesny model...

29 T. Widła, M. Leśniak, “Interdyscyplinarność współczesnej ekspertyzy dokumentów”, Chowanna 2011, 2, pp. 279-298. 
Symposium on Questioned Document Examination. It takes place every two years. At present time the symposium is an opportunity to meet handwriting experts from all over the world.

\section{Conclusions}

As it has already been mentioned at the beginning of the following text, in Poland we need a public discussion concerning some important areas of handwriting science. The first area is connected with the range and quality of the handwriting science study - including personal scientists' responsibility for the methodological accuracy of their research (mainly about an adequate motivation of the results generalization on the whole population). Second area is connected with subject matters responsible for establishing methodological accuracy guidelines concerning procedures of such handwriting science study. How do those guidelines provide for the results of the latest empiric study? Are study methods precisely described and how the quality assurance looks while using them? The third part of the discussion is connected with the experts' certification, so with the way of gaining knowledge and abilities by the expert from particular handwriting science area, and also a formal confirmation of having such knowledge and abilities. There is, however, a concern that if lawyers together with handwriting experts will not react quickly enough, wisely and decisively, in short perspective the accuracy of handwriting science establishment will fall to the level of the accuracy of an inadequately conducted revelation, and the statements about the scientific basics of the methods, used by the handwriting experts, will not be in fact justified.

\section{References}

Buczek A., Leśniak M., “Z badań nad pismem schizofreników w okresie remisji”, Postępy Psychiatrii i Neurologii 2000, no. 9, suplement 1.

Całkiewicz M., Kryminalistyczne badania patologicznego pisma ręcznego, Akademia im. Leona Kuźmińskiego w Warszawie, Warszawa 2009.

Cieśla R., Technical Examination of Documents, Uniwersytet Wrocławski, Wrocław 2006.

Dziewanowska J., Studzińska J., "Assessment of export evidence in Polish Court proceedings in comparison to other European countries", Problems of Forensic Sciences vol. 106, 2016. 
Feluś A., "Indywidualność pisma a pomyłki biegłego", Problemy Kryminalistyki 1985, no. 168 .

Feluś A., “O tzw. nienaukowości ekspertyzy pisma ręcznego", [in:] Z. Kegel (ed.), Materiały XI Wrocławskiego Sympozjum Badania pisma, Uniwersytet Wrocławski, Wrocław 2006.

Feluś A., Podpisy. Studium z pismoznawstwa kryminalistycznego, Uniwersytet Śląski, Katowice 1987.

Gawda B., Pismo a osobowość człowieka, Uniwersytet Marii Curie-Skłodowskiej, Lublin 2000.

Gidrwoyń P., "Rzemiosło czy nauka: sprawy U.S. v. Prime, U.S. v. Saelee, U.S. v. Rutherford", [in:] Z. Kegel (ed.), Wplyw badań eksperymentalnych na wartość dowodowa ekspertyzy dokumentów, Katedra Kryminalistyki WPAiE Uniwersytet Wrocławski, Wrocław 2008.

Goc M., "Poziom kategoryczności wniosków końcowych w opiniach pismoznawczych", Problemy Kryminalistyki 2011, no. 272.

Goc M., Wspótczesny model ekspertyzy pismoznawczej, Wolumina.pl, Warszawa-Szcze$\operatorname{cin} 2015$.

Goc M., Łuszczuk A., Oleksiewicz E., "Dokument jako ślad kryminalistyczny", [in:] M. Goc, J. Moszczyński (eds.), Ślady kryminalistyczne. Ujawnianie, zabezpieczenie, wykorzystanie, Difin, Warszawa 2007.

Gruza E., "Błędy w opiniach biegłych", Problemy Współczesnej Kryminalistyki vol. IX, 2005.

Gruza E., Goc M., Moszczyński J., Kryminalistyka - czyli rzecz o metodach śledczych, Wydawnictwa Akademickie i Profesjonalne, Warszawa 2008.

Kała M., Wilk D., Wójcikiewicz J., Ekspertyza sąowa, Wolter Kluwer, Warszawa 2017. Konieczny J., "Indukcjonistyczne ujęcie dowodu sądowego w procesie karnym", [in:] J. Konieczny (ed.), Materiaty VIII Sympozjum Metodologicznego Kryminalistyki i Nauk Pokrewnych, Uniwersytet Śląski, Katowice 2012.

Konieczny J., "Kryzys czy zmiana paradygmatu kryminalistyki”, Państwo i Prawo 2012, no. 1.

Konieczny J., "Polygraph examination as scientific evidence", European Polygraph vol. 4, 2010.

Koziczak A., Metody pomiarowe w badaniach pismoznawczych, Instytut Ekspertyz Sądowych, Kraków 1997.

Leśniak M., Wartość dowodowa opinii pismoznawczej, B.S.Training, Pińczów 2012.

Leśniak M., Ławrentjew S., "Przesłanki wpisu na listę biegłych zakresu badań dokumentów w sądach okręgowych w Częstochowie, Gliwicach i Katowicach - analiza praktyki", [in:] R. Cieśla (ed.), Dokument i jego badania, Katedra Kryminalistyki Wydziału Prawa, Administracji i Ekonomii Uniwersytetu Wrocławskiego, Wrocław 2014.

Matuszewski S., "Natural variation in length of signature components", Problems of Forensic Science vol. 87, 2011. 
Pobocha J., Legień M., “Zmiany poalkoholowe w piśmie ręcznym”, Problemy Kryminalistyki 1981, no. 151-152.

Sachs M.J., Koehler J.K., "The coming paradigm shift in forensic identification science", Nature vol. 309, 2005.

Skubisz S., Dowód z ekspertyzy pisma patologicznego, Wolters Kluwer, Kraków 2004.

Tomaszewski T., "Badania pismoznawcze w Stanach Zjednoczonych: rzemiosło czy nauka”, [in:] Z. Kegel (ed.), Wplyw badań eksperymentalnych na wartość dowodowa ekspertyzy dokumentów, Katedra Kryminalistyki WPAiE Uniwersytet Wrocławski, Wrocław 2008.

Tomaszewski T., "Czynniki uwzględniane w badaniach autentyczności podpisów”, Człowiek i Dokumenty 2010, no. 16.

Widacki J., Wartość diagnostyczna badania poligraficznego i znaczenie kryminalistyczne, Uniwersytet Jagielloński, Kraków 1976.

Widacki J. (ed.), Kryminalistyka, C.H. Beck, Warszawa 2012.

Widła T., Cechy płci w piśmie ręcznym, Uniwersytet Śląski, Katowice 1986.

Widła T., Ocena dowodu z opinii biegłego, Uniwersytet Śląski, Katowice 1992.

Widła T., Leśniak M., “Interdyscyplinarność współczesnej ekspertyzy dokumentów”, Chowanna, 2011, no. 2, http://statystyka.policja.pl/st/kodeks-karny/przestepstwa-przeciwko15/63643,Podrabianie-dokumentow-art-270.html.

Widła T., Z problematyki patologii pisma, [in:] H. Kołecki (ed.), Kryminalistyka i nauki penalne wobec przestępczości, Wydawnictwo Poznańskie, Poznań 2008.

Wójcikiewicz J., Dowód naukowy w procesie sądowym, Wydawnictwo Instytutu Ekspertyz Sądowych, Kraków 2000.

\section{Summary}

The present text is about situation of handwriting examinations currently in Poland. The scientific condition of handwriting examinations and the position taken in practice were presented. In context of statistical date this kind of expert's opinion may be very significant for judicial proceedings. Meanwhile, the court decision-makers are not appropriately trained for making an assessment of experts' opinions. Qualifications of handwriting experts are often poor. The dispute about scientific character of comparative examinations is continued. The system of controlling of expert's opinions quality is not introduced. At the same time Polish scientists do a lot of interesting research on different issues concerning handwriting. Inter alia the researchers deal with: measuring of handwriting characteristics, influences somatic or mental disorders on handwriting, new techniques of graphical and comparative analysis, frequency signatures' characteristics.

Keywords: handwriting examination, an expert's opinion, handwriting characteristics, comparative examination, forensic researches in Poland, an expert's conclusion, quality of forensic examination, criteria of being a scientific method. 